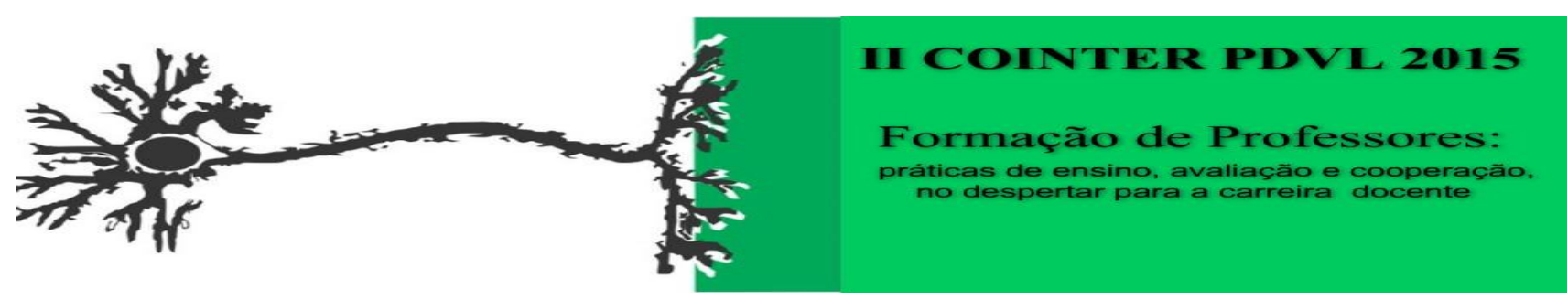

\title{
O USO DA INTERNET COMO FERRAMENTA PEDAGÓGICA NAS OFICINAS DE CUSTOMIZAÇÃO DO VESTUÁRIO EM COMUNIDADES DO SEMIÁRIDO PERNAMBUCANO: RELATO DE EXPERIÊNCIA
}

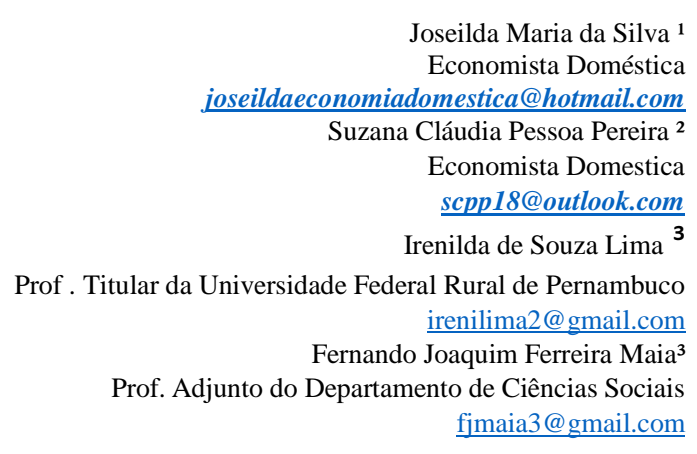

\section{Introdução}

O presente trabalho tem por objetivo relatar a experiência de estágio vivenciada como discente do curso de Economia Doméstica, no Projeto Universidade Cidadã, em parceria com o COEP Comitê de Entidades no Combate á Fome e pela Vida com as Universidades Públicas do Nordeste, que busca a participação das universidades na implantação de projetos de desenvolvimento comunitário. Teve por objetivo desenvolver ações que mediante o trabalho com grupos de mulheres rurais, contribuíssem para a promoção do desenvolvimento local e consolidassem os conhecimentos adquiridos ao longo da formação em Economia Doméstica.

\section{Relato de Experiência}

O semiárido pernambucano é historicamente marcado pelo discurso do combate à seca. A população dessas localidades enfrentam altos índices de desemprego e exclusão sociais provocadas pelas práticas politicas e econômica do nosso país. Essa população enfrenta uma realidade marcada por muitas dificuldades, seca, descaso, desemprego, pobreza, exclusão, indiferença e desigualdades sociais crescentes. Diante do exposto o Projeto Universidade Cidadã teve como propósito desenvolver ações para o desenvolvimento local, implementando ações que colaborassem para a geração de trabalho e renda com iniciativas de educação e capacitação, atuando em comunidades rurais de baixa renda, no semiárido. Nas comunidades do COEP do semiárido a implantação dos telecentros assume status estratégico e se insere aquilo que se convencionou chamar de inclusão digital. A importância dos telecentros nessas comunidades deve-se ao potencial de uso da informática relacionado ás linhas de ações do COEP no semiárido: Educação e Cidadania; convivência com a seca; trabalho e renda e organização comunitária. O uso das tecnologias nos telecentros cria condições desencadeadoras de processos de ensino-aprendizagem que favorece ações de educação. Em tempos de globalização e do que se convencionou denominar sociedade do 
conhecimento o acesso á informação e ao conhecimento sistematizado se coloca como peça-chave nesse processo, a partir do qual muitos caminhos dentro do ambiente social, politico e econômico podem ser comtemplados. Para Rondelli,(2003), á priori essa possibilidade ocorre mediante o contato com as tecnologias da informação seja através do reconhecimento inicial do conteúdo em formato digital, do uso de ferramentas, na produção do conhecimento, ou da construção de novas ferramentas capazes de atender ás demandas permanentes do mundo da informação. O estágio teve por objetivos, desenvolver ações com grupos de mulheres rurais, com as oficinas de customização contribuindo para a geração de trabalho e renda e para o desenvolvimento local. $\mathrm{O}$ uso da internet possibilitou que elas se habilitassem a utilizarem os computadores como ferramentas pedagógicas motivando assim a desenvolverem sua criatividade para as suas atividades produtivas. A equipe buscou a utilização da internet como uma forma de adquirir conhecimento e desenvolver nas participantes a conscientização e estimulo da utilização da tecnologia como instrumento de trabalho.

Imagem 1: Comunidade de Pilões - Cumaru /PE Fonte: Própria

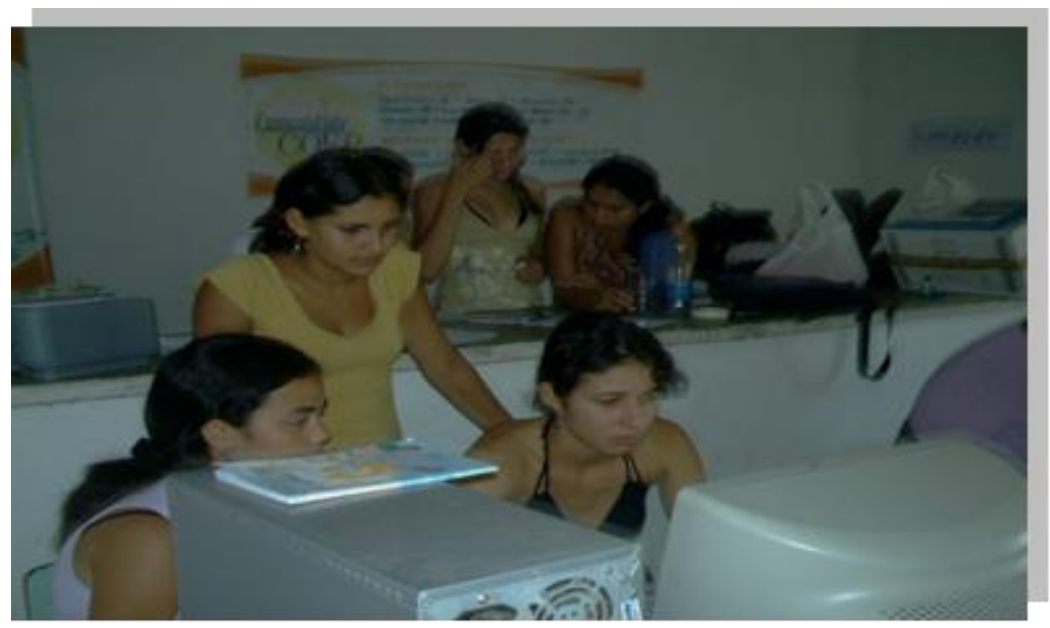

\section{Considerações}

Não há dúvida quanto á pertinência desses telecentros nas comunidades, contudo, há que se dar prioridade a boa gestão desse recurso. Deve-se trabalhar na perspectiva da comunidade se acostumar cotidianamente com a importância desse recurso, para informação, organização comunitária e principalmente como ferramenta pedagógica na educação.

\section{Referências}

RONDELLI, Elizabeth. Quatro passos para inclusão digital. Revista I- coletiva. 2003. 
